\title{
RNAi-Mediated Resistance to Bean golden mosaic virus in Genetically Engineered Common Bean (Phaseolus vulgaris)
}

\author{
Kenny Bonfim, ${ }^{1,2}$ Josias C. Faria, ${ }^{3}$ Elsa O. P. L. Nogueira, ${ }^{1}$ Érica A. Mendes, ${ }^{1}$ and Francisco J. L. Aragão ${ }^{1,2}$ \\ ${ }^{1}$ Embrapa Recursos Genéticos e Biotecnologia, PqEB W5 Norte, 70770-900, Brasília, DF, Brazil; ${ }^{2}$ Universidade de Brasília, \\ Departamento de Biologia Celular, Campus Universitário, 70910-900, Brasília, DF, Brazil; ${ }^{3}$ Embrapa Arroz e Feijão, Rodovia \\ GO-462, km 12 Zona Rural C.P. 179, 75375-000 Santo Antônio de Goiás, GO, Brazil
}

Submitted 7 November 2006. Accepted 24 January 2007.

Bean golden mosaic virus (BGMV) is transmitted by the whitefly Bemisia tabaci in a persistent, circulative manner, causing the golden mosaic of common bean (Phaseolus vulgaris L.). The characteristic symptoms are yellow-green mosaic of leaves, stunted growth, or distorted pods. The disease is the largest constraint to bean production in Latin America and causes severe yield losses (40 to 100\%). Here, we explored the concept of using an RNA interference construct to silence the sequence region of the $A C 1$ viral gene and generate highly resistant transgenic common bean plants. Eighteen transgenic common bean lines were obtained with an intron-hairpin construction to induce posttranscriptional gene silencing against the $A C 1$ gene. One line (named 5.1) presented high resistance (approximately $\mathbf{9 3 \%}$ of the plants were free of symptoms) upon inoculation at high pressure (more than 300 viruliferous whiteflies per plant during the whole plant life cycle) and at a very early stage of plant development. Transgene-specific small interfering RNAs were detected in both inoculated and noninoculated transgenic plants. A semiquantitative polymerase chain reaction analysis revealed the presence of viral DNA in transgenic plants exposed to viruliferous whiteflies for a period of 6 days. However, when insects were removed, no virus DNA could be detected after an additional period of 6 days.

Additional keywords: Begomovirus, geminivirus, RNA interference.

Bean golden mosaic virus (BGMV) belongs to genus Begomovirus (family Geminiviridae). The majority of the Begomovirus genome comprises two single-stranded DNA molecules, designated as DNA-A and DNA-B, both of which are essential for infectivity. Genes from DNA-A encode proteins responsible for viral replication ( $A C 1$ and $A C 3)$, regulation of gene expression (AC2), and particle encapsidation $(A V 1)$, whereas two genes from DNA-B encode proteins involved in cell-tocell and long-distance movement with plant tissues and host range and symptom modulation (Hanley-Bowdoin et al. 1999; Vanitharani et al. 2005). ACl encodes a complex, multifunc-

Corresponding author: F. J. L. Aragão; Telephone and Fax: +55-6134484777; E-mail: aragao@cenargen.embrapa.br

* The $\boldsymbol{e}$-Xtra logo stands for "electronic extra" and indicates that Figure 3 appears in color online. tional protein (Rep) that acts as a rolling-circle replication initiation factor, which is the only protein strictly essential for viral genome replication and is capable of regulating its own expression (Eagle et al. 1994; Elmer et al. 1988), whereas AC3 encodes a replication enhancer protein (REn) (Sunter et al. 1990). AC2 encodes a transcriptional regulatory protein (TrAP), which is required for efficient transcription of both $A V 1$ and BV1 genes (Sunter and Bisaro 1992, 1997). In addition, TrAP interacts and inactivates SNF1 and adenosine kinases involved in defense response (Hao et al. 2003; Wang et al. 2003). Furthermore, it has been suggested that it acts as a suppressor of RNA silencing (Trinks et al. 2005; Vanitharani et al. 2005; Wang et al. 2005).

BGMV is transmitted by the whitefly Bemisia tabaci (Gennadius) in a persistent, circulative manner, and causes the golden mosaic of common bean (Phaseolus vulgaris L.). The characteristic symptoms are yellow-green mosaic of leaves, stunted growth, or distorted pods. Control measurements have been focused primarily on controlling the vector by contact or systemic insecticides, with the concomitant problems of development of insecticide resistance, low cost-benefit ratio, and environmental concerns. The disease is the largest constraint to bean production in Latin America and causes significant yield losses (40 to 100\%) in South and Central America, Mexico and the United States (Morales 2006; Morales and Anderson 2001). In Latin America, BGMV causes severe yield losses, particularly during the warmer months when the $B$. tabaci population is higher, leading to a great reduction of summer plantings of common bean. Extensive screening of common bean germ plasm for resistance to BGMV has revealed no genotypes with high levels of resistance. The resistance often is unsatisfactory and commercial cultivars are susceptible under early, moderate, or severe infection (Garrido-Ramirez et al. 2000; Morales and Anderson 2001; Seo et al. 2004).

Several strategies have been employed for genetically engineering resistance to viruses in transgenic plants. For begomoviruses, most of them have involved the expression of truncated defective genes (Antignus et al. 2004; Brunetti et al. 1997, 2001; Chellappan et al. 2004a; Duan et al. 1997; Hong and Stanley 1996; Kunik et al. 1994; Lucioli et al. 2003; Noris et al. 1996; Yang et al. 2004) and antisense RNA (Asad et al. 2003; Bejarano and Lichtenstein 1994; Bendahmane and Gronenborn 1997; Day et al. 1991; Zhang et al. 2005). We have used antisense RNA successfully to produce transgenic common bean showing delayed and attenuated golden mosaic symptoms upon whitefly-mediated inoculation (Aragão et al. 1998). Expression of ACl-double-stranded RNA (dsRNA) re- 
vealed reliable resistance to Cotton leaf curl virus in transgenic tobacco (Asad et al. 2003) and to Tomato yellow leaf curl virus (TYLCV)-[Is] in transgenic tomato (Yang et al. 2004). Transient expression of dsRNA targeting the common region of the Vigna mungo yellow mosaic virus in Vigna spp. resulted in recovery from virus infection (Poogin et al. 2003).

RNA interference (RNAi) is a post-transcriptional genesilencing mechanism that mediates resistance to both endogenous parasitic and exogenous pathogenic nucleic acids, as well as regulates the expression of protein-coding genes (Herr 2005). The potential of constructs encoding self-complementary hairpin RNA (hpRNA) to efficiently silence genes in plants has been demonstrated (Wesley et al. 2001). The self-complementary RNA transcripts form a dsRNA that triggers a sequencespecific mRNA degradation in a process known as RNAi. dsRNA is processed by an RNase III, called Dicer, into small interfering RNAs (siRNAs). The strand of siRNA complementary to the target RNA becomes incorporated into a multiprotein complex (RISC) leading to mRNA degradation and gene silencing. It has been found that DNA viruses, including geminiviruses, are capable of inducing gene silencing (Bian et al. 2006; Chellappan et al. 2004b; Fuentes et al. 2006; Kjemtrup et al. 1998; Vanitharani et al. 2003).

In this article, we explore the RNAi concept to silence the $A C l$ viral gene in common bean to generate transgenic lines with strong resistance to BGMV. We report here the successful engineering of high resistance to the geminivirus displayed by one transgenic line. The resistance is correlated with post-tran- scriptional gene silencing (PTGS) through the production of transgene-specific siRNAs.

\section{RESULTS}

hpRNA construct and plant transformation.

To assess the effectiveness of siRNA to produce common bean plants resistant to BGMV by silencing the $A C l$ viral gene, we generated an intron-spliced hpRNA vector (pBGMVRNAiAHAS) into which an $A C 1$ gene fragment was directionally cloned to generate sense and antisense arms (Fig. 1). Of 2,706 embryonic axes bombarded with the vector pBGMVRNAiAHAS, 18 common bean transgenic lines were produced, presenting a transformation efficiency of $0.66 \%$. All primary transformants $\left(\mathrm{R}_{0}\right)$ contained both ahas and $\triangle A C l$ cassettes and showed a normal phenotype.

\section{Plant inoculation and symptom screening.}

Primary transformants were tested for resistance to BGMV by inoculation with viruliferous whiteflies. Except for line 5.1, all 17 other primary transformants were susceptible to the virus. Line 5.1 was phenotypically immune and was allowed to set seed. Subsequent experiments focused on this transgenic line. The $F_{1}$ generation was cultivated in the greenhouse and presented normal phenology (plant height, site of insertion of first pod, number of branches, internode length, foliar area, and total number of flowers and pods). Polymerase chain reaction (PCR) analysis revealed non-Mendelian segregation. Of 15
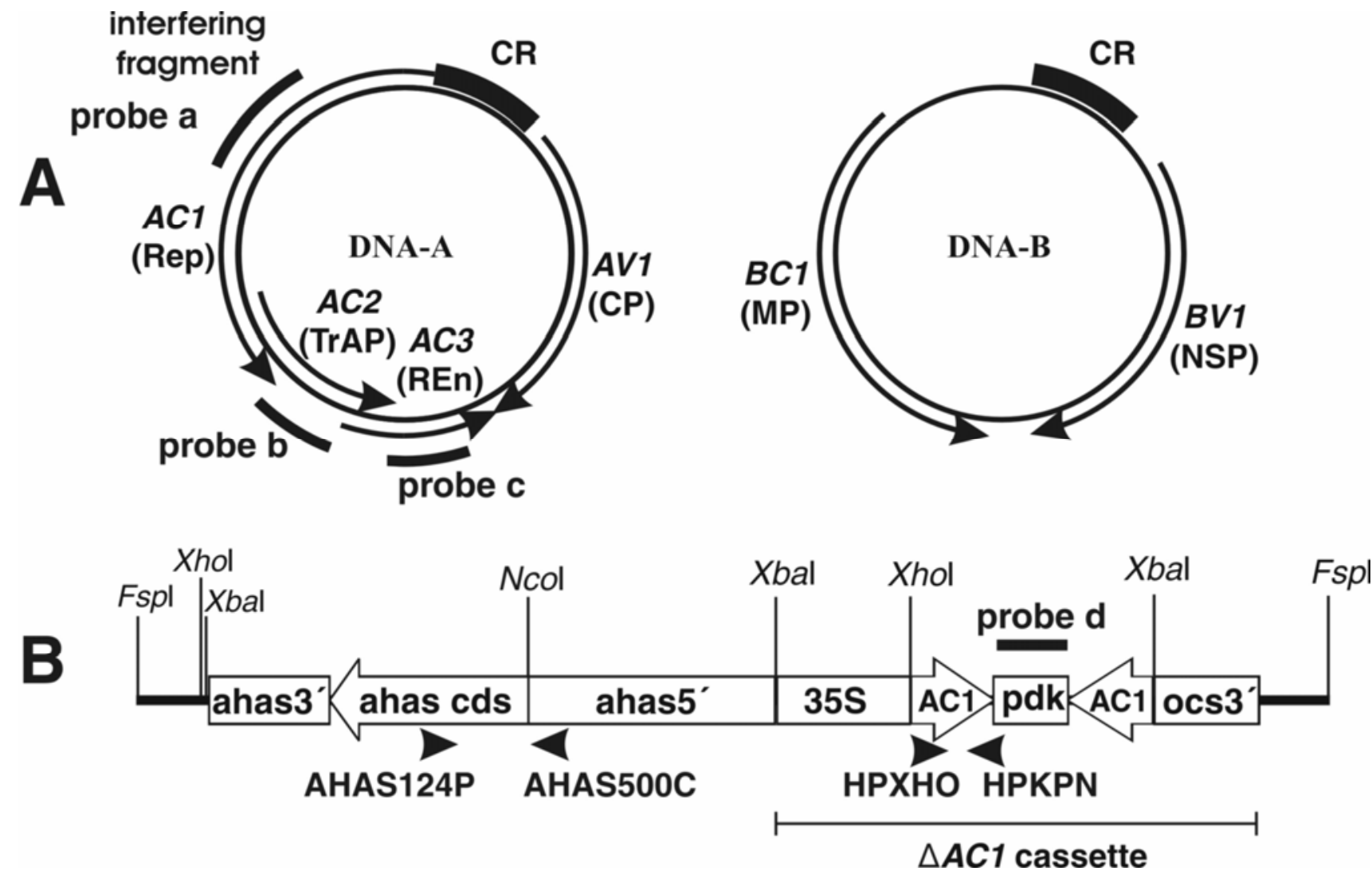

Fig. 1. Diagram representing the Bean golden mosaic virus BGMV genome and the fragment vector used to transform common bean plants. A, BGMV genome organization showing the two components (denoted DNA-A and DNA-B) which encode genes involved in expression, replication, or encapsidation $(A C 1, A C 2, A C 3$, and $A V 1)$ and movement ( $B C 1$ and $B V 1)$, respectively; and the $A C 1$ fragment (interfering fragment) used for the construction of the intronhairpin RNA expression cassette. CR corresponds to the common region. B, Map of pBGMVRNAiAHAS fragment containing the ahas gene (ahas5': ahas gene promoter; ahas cds: Arabidopsis thaliana AHAS coding sequence; ahas3': ahas gene terminator) and the $\triangle A C 1$ cassettes (35S: $35 S$ promoter of Cauliflower mosaic virus; intron: Flaveria trinervia pdk intron; ocs3': octopine synthase terminator). AC1 interfering fragment was cloned in sense and antisense orientations. Small arrows indicate primers used for polymerase chain reaction screening. Solid bars in A and B represent probes used for RNA interference (probes a, b, and c) and Southern blot analysis (probe d). 
plants, only three revealed the presence of transgenes $\left(\chi^{2}=\right.$ 24.2, $P=0.01,1 \mathrm{df}$; testing ratio of 3:1) (Fig. 2). Plants were exposed to 60 viruliferous whiteflies and all transgenic plants remained without virus symptoms and were allowed to set seed. Of 58 plants ( $\mathrm{F}_{2}$ generation), 42 revealed the presence of both ahas and $\triangle A C l$ transgenes, presenting a Mendelian segregation pattern of $3: 1\left(\chi^{2}=0.2, P=0.64,1 \mathrm{df}\right)$ (Fig. 2). Except for three plants, all transgenic plants revealed immunity to the BGMV and PCR analysis revealed an absence of viral DNA in the symptomless plants. The three infected plants showed normal growth and showed mild symptoms in leaves from the top of the plant 30 days after virus inoculation (Fig. 3). All segregating (not containing the transgenes) and nontransgenic plants (controls) revealed characteristic severe symptoms of the golden mosaic disease (yellow-green mosaic in leaves, stunted growth, and distorted pods) 2 weeks after virus inoculation (Fig. 3).

Using PCR analysis, it was possible to identify two homozygous sublines in the $\mathrm{R}_{2}$ generation (Fig. 2). In all, 32 homozygous transgenic plants and 20 nontransgenic plants were highly inoculated with the virus, using viruliferous whiteflies (135 to 357 whiteflies per plant), for 6 days. The results showed that 94.1 and $100 \%$ plants for both transgenic sublines remained without symptoms, whereas all nontransgenic plants revealed severe symptoms 29 days after inoculation (Fig. 2). PCR analysis showed that the virus DNA was absent in the transgenic plants (data not shown).

\section{Genomic analysis.}

Southern blot analysis of genomic DNA isolated from line 5.1 was carried out to evaluate the integration of the $\triangle A C 1$ cassette (Fig. 4). Because it was used as a linearized vector for bean transformation, Southern analysis using genome diges- tion with $\mathrm{XhoI}$ revealed that all transgenic plants analyzed presented the same pattern, suggesting that transgene copies were not independently segregating in the $\mathrm{R}_{2}$ generation of self-pollinated plants. DNA isolated from a nontransgenic plant did not hybridize with the $\triangle A C 1$ cassette probe.

siRNA in transgenic plants.

Northern analyses were carried out to detect the siRNA in inoculated leaves of transgenic and nontransgenic bean plants. Plants were maintained in contact with viruliferous whiteflies (200 to 350 whiteflies per plant) for a period of 6 days; then, the insects were removed. At day 6 and 12, transgenic and nontransgenic leaves were analyzed for the presence of siRNA (Fig. 5). The analysis showed siRNA bands of expected size range in both inoculated and noninoculated transgenic plants (Fig. 5A). The amount of transgene-derived siRNA did not significantly increase. No signal was observed in either inoculated or noninoculated nontransgenic plants. Signals corresponding to inoculated transgenic leaves were slightly more intense than those observed in noninoculated transgenic plants. However, it detected the presence of siRNAs only representing parts of the target RNA. No signal was observed when probes outside the region homologous to the triggering $A C l$ gene were used (Fig. 5B and C). All nontransgenic plants inoculated with the virus developed typical mosaic symptoms, whereas all inoculated transgenic plants did not show virus symptoms.

A semiquantitative PCR analysis was carried out to detect and estimate viral DNA accumulation in the same leaves analyzed for the presence of siRNA (Fig. 5D). At day 6, viral DNA was detected in inoculated transgenic leaves. However, at day 12, no signal was observed. A strong signal was observed in nontransgenic inoculated leaves either 6 or 12 days after inoculation. Noninoculated leaves did not present any signal.
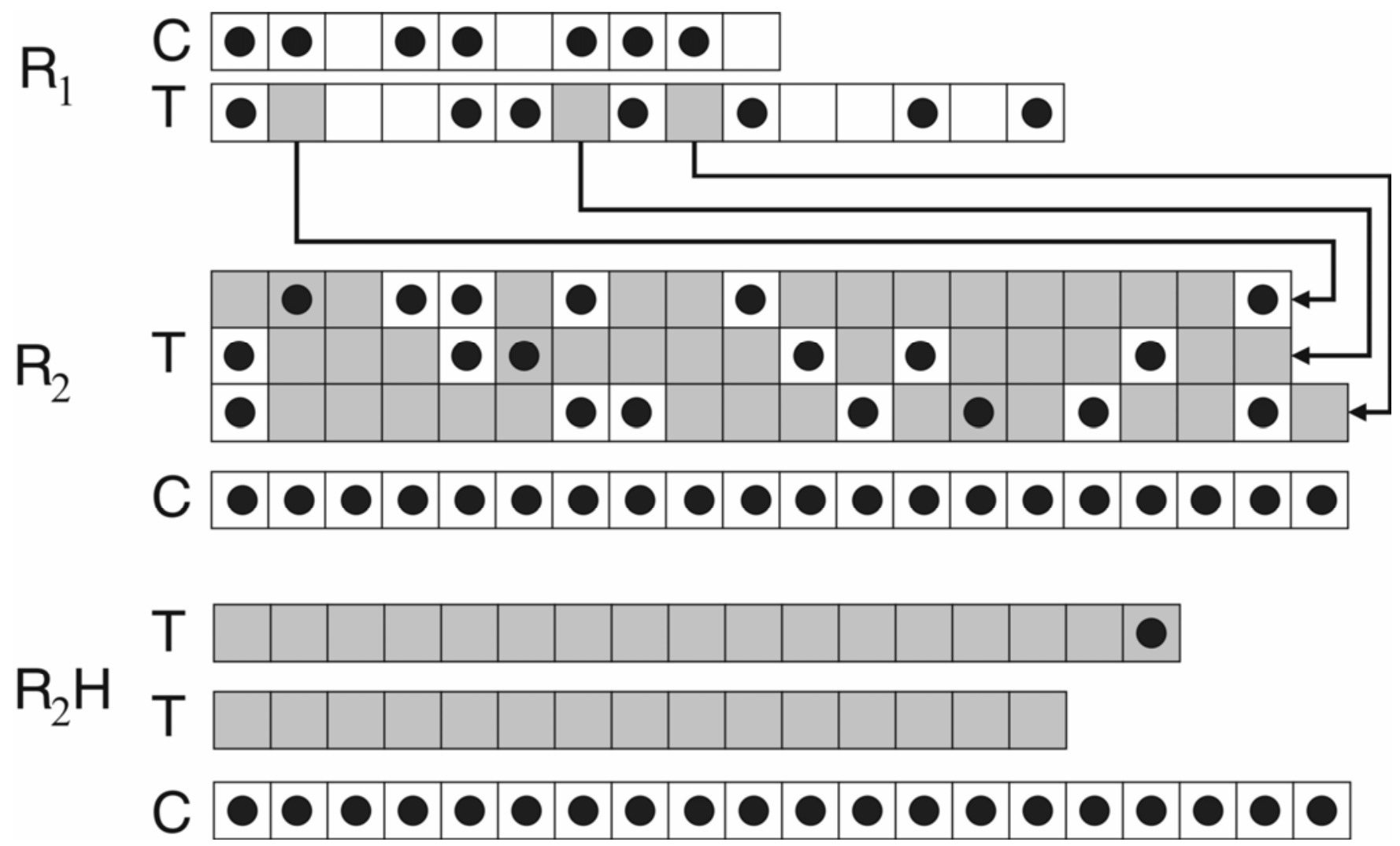

Fig. 2. Schematic representation of the transgenic (gray boxes) and nontransgenic (white boxes) plants in the first generation $\left(R_{1}\right)$ and in heterozygous $\left(R_{2}\right)$ and homozygous $\left(\mathrm{R}_{2} \mathrm{H}\right)$ lines in the second generation. Plants showing Bean golden mosaic virus symptoms are marked with a solid dot. Arrow indicates progenies $\left(\mathrm{R}_{2}\right.$ generation) derived from the three transgenic plants identified in the first generation. $\mathrm{C}$ represents control (nontransgenic plants). 
Northern analyses were carried out to detect $A C l$-specific siRNA in leaves of transgenic plants maintained for a period of 5 days at different temperatures $\left(15,25\right.$, and $\left.35^{\circ} \mathrm{C}\right)$. When compared with the amount of siRNA found at $25^{\circ} \mathrm{C}$, results showed a slight decrease in the amount of accumulated siRNA at $15^{\circ} \mathrm{C}$ and a decrease in smaller siRNA at $35^{\circ} \mathrm{C}$ (Fig. 6).

\section{Comparison of BGMV resistance in plants expressing a hairpin RNA (RNAi strategy) and a mutated rep gene (transdominance strategy).}

To compare the resistance of line 5.1 with a partially resistant transgenic bean line expressing a mutated Rep protein (line M1-4) (Faria et al. 2006), homozygous plants were germinated in the presence of a viruliferous whitefly colony. The number of whiteflies was estimated to be at an average of 100 individuals per plant at the beginning of the inoculation, and more than 300 insects per plant at the end of inoculation period (38 days). Results revealed that 28 of 29 plants (96.6\%) from line M1-4 presented symptoms whereas, for line 5.1 , only 2 of 28 plants $(7.1 \%)$ presented symptoms, and all nontransgenic plants had severe symptoms (Fig. 7). In addition, a remarkable delay in the appearance of viral symptoms was observed in those two plants of line 5.1. The viral DNA could not be detected by PCR in plants that were free of symptoms.

\section{DISCUSSION}

Geminivirus diseases, particularly bean golden mosaic, are the most important constraint to the production of common bean and vegetable crops in the tropical lowlands and mid-altitude valleys of Latin America (Morales 2006). Control measures in infected regions are based on the chemical control of the vector population, with partial efficacy, environmental negative effect, elimination of natural enemies, and appearance of pesticide-resistant whitefly. Thus, the best way to control the disease in the field is to achieve genetic resistance to or tolerance for the virus. In this study, we hypothesized that silencing the $A C l$ viral gene expression by sequence-specific degradation of target mRNA interfering with viral replication would reduce or prevent viral DNA accumulation and, consequently, appearance of symptoms.
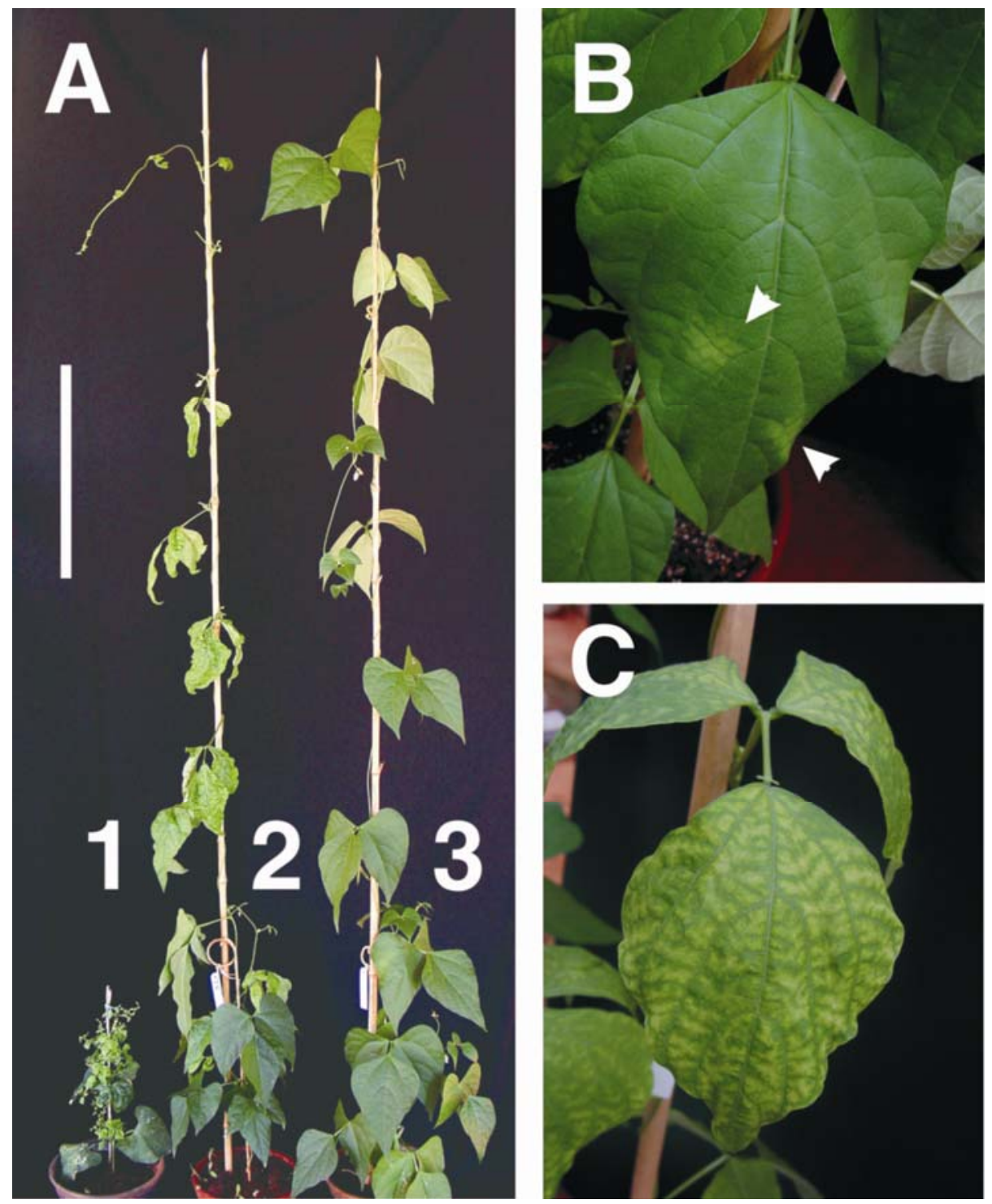

Fig. 3. Golden mosaic disease symptom in whitefly Bean golden mosaic virus-inoculated transgenic and nontransgenic common bean plants. A, Nontransgenic plant (1) presenting severe symptoms, transgenic plant presenting mild symptoms (2) or symptom free (3). Approximately $7 \%$ of transgenic plants present mild and delayed symptoms, $\mathbf{B}$, which start with yellowing areas (arrows) in the leaves from the top, then $\mathbf{C}$, progress to the whole leaf. Images were taken 35 days after inoculation. A, Bar represents $50 \mathrm{~cm}$. 
Advances in molecular biology have led to the development of pathogen-derived resistance, in which the expression of a pathogen-derived gene or sequence in a plant provides resistance to the pathogen. Many examples of this engineered resis-

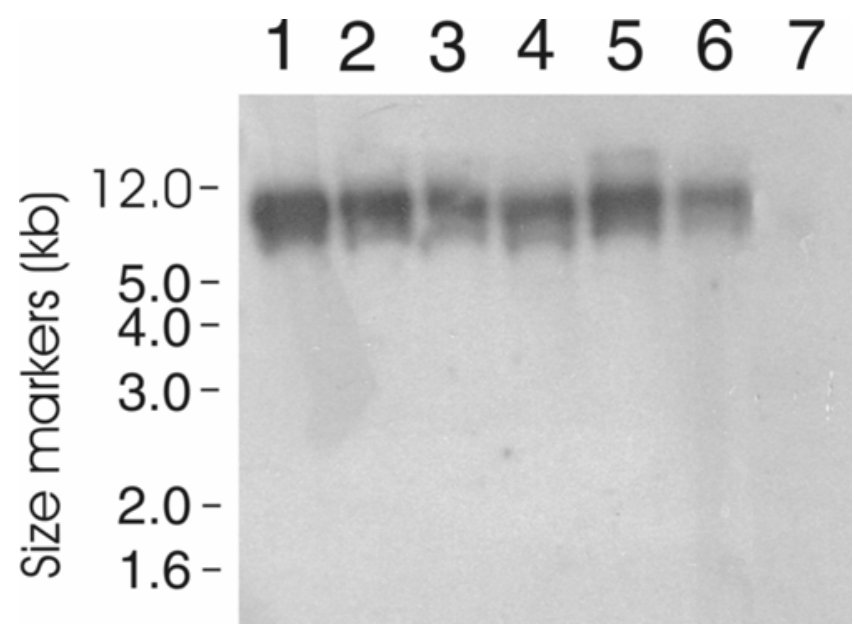

Fig. 4. Southern blot analysis of genomic DNA to detect the foreign $\triangle A C 1$ cassette in common bean plants ( $R_{2}$ generation) from transgenic line 5.1. Lanes 1 to 6: transgenic plants; lane 7: nontransgenic plant. Hybridization was carried out with probe $d$. tance to RNA plant viruses have been presented. However, there are relatively fewer reports of engineered resistance to DNA viruses, and most of the experiments have been carried out in model plants (Prins 2003; Vanderschuren et al. 2006). Defective viral DNA, antisense $A C 1$ gene, defective AC1 protein, defective movement protein, and coat protein have been employed with varying success rates (Aragão et al. 1998; Bejarano and Lichtenstein 1994; Bendahmane and Gronenborn 1997; Day et al. 1991; Hong and Stanley 1996; Kunik et al. 1994; Noris et al. 1996; Stanley et al. 1990; von Arnim and Stanley 1992; Yang et al. 2004). However, most of the previously described transgenic plants had no immune response and the conferred resistance was moderate. The use of siRNAs, an intermediate in the gene-silencing pathway, has become a powerful tool for specifically downregulating gene expression, as has been demonstrated successfully in a wide variety of cells and organisms (Waterhouse et al. 2001). It was recognized that an RNA-silencing (PTGS) mechanism was responsible for the resistance against RNA viruses, and that it depends on the formation of dsRNA, whose antisense strand is complementary to the transcript of a targeted gene (Brodersen and Voinnet 2006; Herr 2005). This discovery led to the introduction in transgenic plants of constructs to produce intracellular generation of siRNA-like species to efficiently induce targeted gene silencing and virus resistance. Constructs encoding selfcomplementary hpRNA have been shown to be capable of gen-

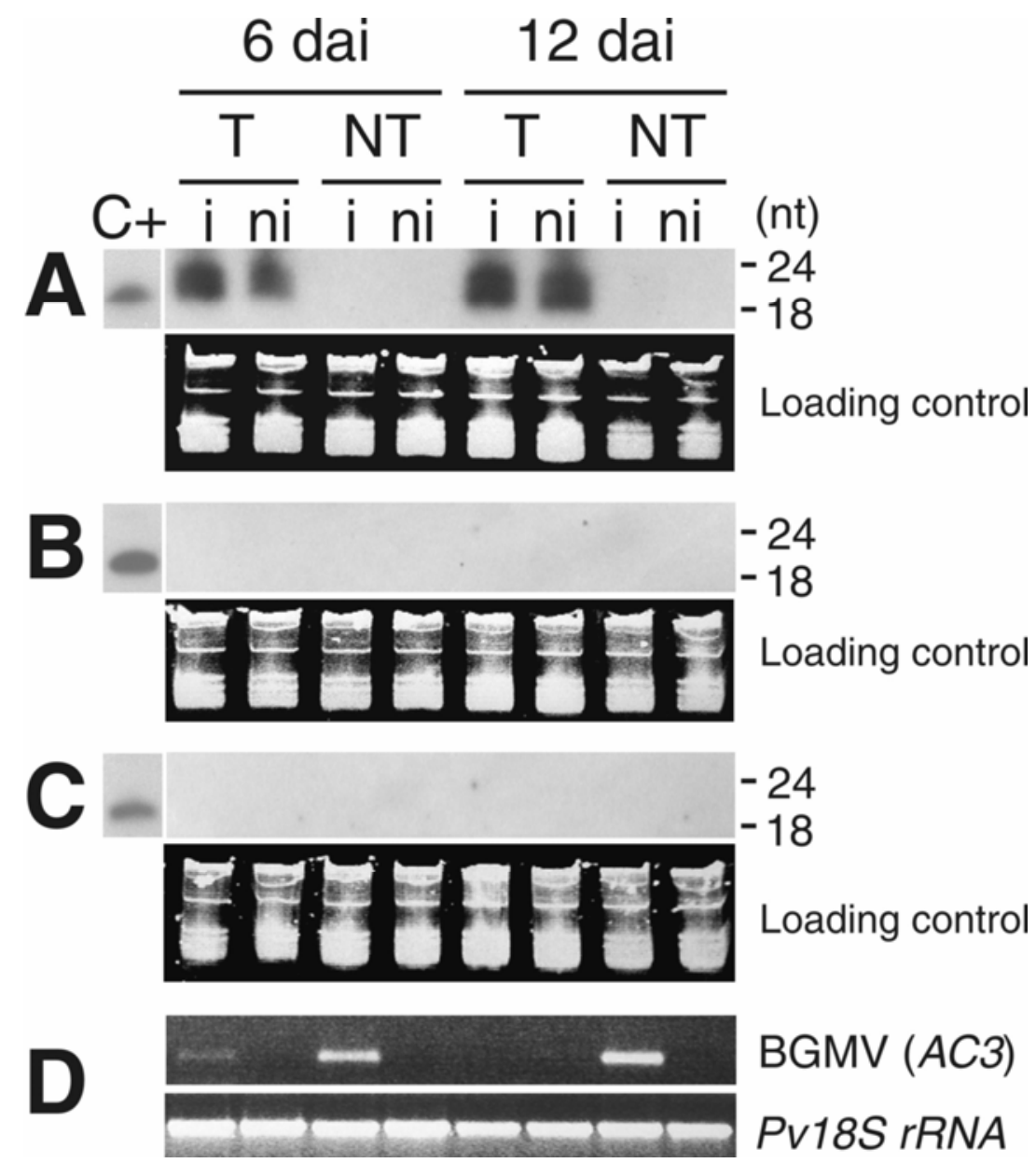

Fig. 5. Northern blot analysis of small interfering (si)RNA isolated from intron-hairpin RNA-transformed common bean plants. Plants were maintained in contact with viruliferous whiteflies for a period of 6 days. RNA was isolated from the primary leaves at days 6 and 12 from transgenic (T) and nontransgenic (NT) plants, inoculated (i) and noninoculated (ni) with Bean golden mosaic virus (BGMV). RNA blots were probed to detect the presence of siRNA molecules corresponding to $\mathbf{A}, A C 1, \mathbf{B}, A C 2$, and $\mathbf{C}, A C 3$ mRNA sequences. C+: $50 \mathrm{ng}$ of a BGMV $A C 1$ (in A), $A C 2$ (in B), and $A C 3$ (in C) gene-derived oligomers. Ethidium bromidestained RNA serves as the loading control. All transgenic plants remained free of symptoms, whereas all nontransgenic plants had severe symptoms. D, The virus DNA was detected in a semiquantitative polymerase chain reaction. The genomic Pv18SrRNA gene was used as internal control. 
erating post-transcriptional silence to undetectable levels of the targeted mRNA transcript (Nunes et al. 2006; Wesley et al. 2001). Using this type of construct containing the common region of the begomovirus Vigna mungo yellow mosaic virus in a transient assay, Pooggin and associates (2003) obtained recovery from virus infection. Vanitharani and associates (2003) reported that the use of siRNAs blocked the accumulation of the AC1 mRNA of the geminivirus African cassava mosaic virus (ACMV) in cultured plant cells. Tobacco plants engineered to express the $3^{\prime}$ and $5^{\prime}$ regions from the ACl gene from Cotton leaf curl virus, in sense and antisense orientations, revealed high resistance to the virus after continuous exposure to viruliferous whiteflies (Asad et al. 2003). Recently, Fuentes and associates (2006) reported immunity against the TYLCV in transgenic tomato plants transformed with an intron-hairpin construction produced with 726 bp within the $C 1$ viral gene. Tomato plants transformed with an intron-hairpin construct from the $C 2$ gene of Tomato leaf curl virus (TLCV) and presenting C2-specific siRNA accumulation developed mild symptoms at 20 to 25 days after virus inoculation (Bian et al.

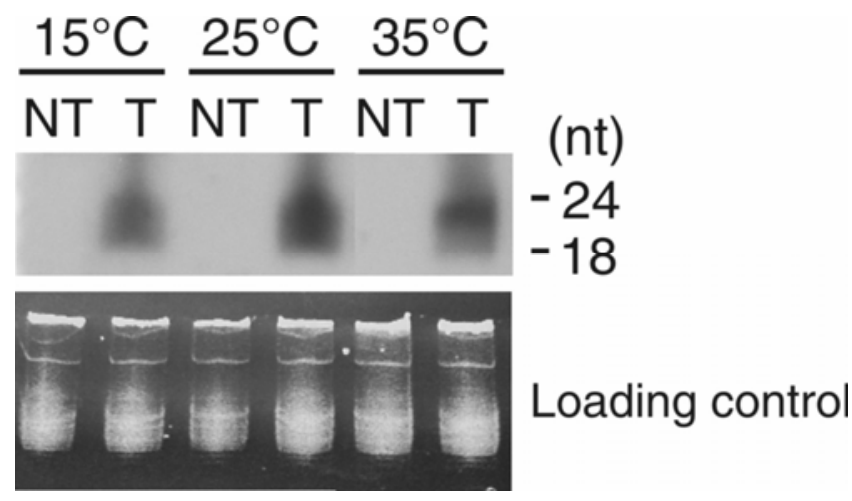

Fig. 6. Northern blot analysis of small interfering RNA isolated from intronhairpin RNA-transformed common bean plants exposed to different temperatures. Noninoculated transgenic plants were maintained for a period of 5 days at $15^{\circ} \mathrm{C}$ (lanes 1 and 2 ), $25^{\circ} \mathrm{C}$ (lanes 4 and 5), and $35^{\circ} \mathrm{C}$. nt $=n u-$ cleotides; $\mathrm{NT}=$ nontransgenic plants; $\mathrm{T}=$ transgenic plants..
2006). In contrast, tomato plants engineered through RNAi strategy to silence the rep (C1) gene of Tomato yellow leaf curl Sardina virus accumulated high amounts of specific siRNA but were susceptible to the virus when challenged by agroinoculation or use of high viruliferous whitefly pressure (Noris et al. 2004).

$\mathrm{AC} 1$ is the only protein strictly essential for viral genome replication and probably abundant early in the infection cycle; therefore, it seems to be an obvious target for disrupting the virus cycle by biotechnological approaches. Our results showed that $A C 1$ gene-based RNAi is an effective strategy to achieve high resistance to BGMV in genetically modified common bean. In addition, the resistant line generated in this study showed remarkable resistance when compared with a recently generated transgenic bean line expressing a mutated $A C l$ gene (transdominance strategy) (Faria et al. 2006).

The ability to genetically engineer common bean is still not trivial (Veltcheva et al. 2005), and the previously reported efficiency of transformation using linearized vectors was $0.2 \%$ (Vianna et al. 2004). Use of linear vectors is important to eliminate undesirable antibiotic selective genes. One important constraint to the transformation system based on bombardment of meristematic tissues of embryonic axes is the difficulty of having an efficient selection for transformed meristematic cells because only a few are transformed. We used a novel system for selecting transformed meristematic cells based on the use of imazapyr, an herbicidal molecule capable of systemically translocating and concentrating in the apical meristematic region of plant embryos. This selectable marker resulted in a significant increase (threefold) in the recovery of fertile, transgenic lines compared with the standard common bean transformation protocol (Vianna et al. 2004). The improvement in the bean transformation technology was essential for obtaining a larger number of transgenic lines, increasing the probability to select transformation events presenting virus immunity.

Of 18 common bean transgenic lines tested for resistance to BGMV, one line (5.1) remained without virus symptoms and was further analyzed. The resistance frequency was very low when compared with those observed for RNA viruses. It has been shown that gene constructs encoding intron-spliced RNA

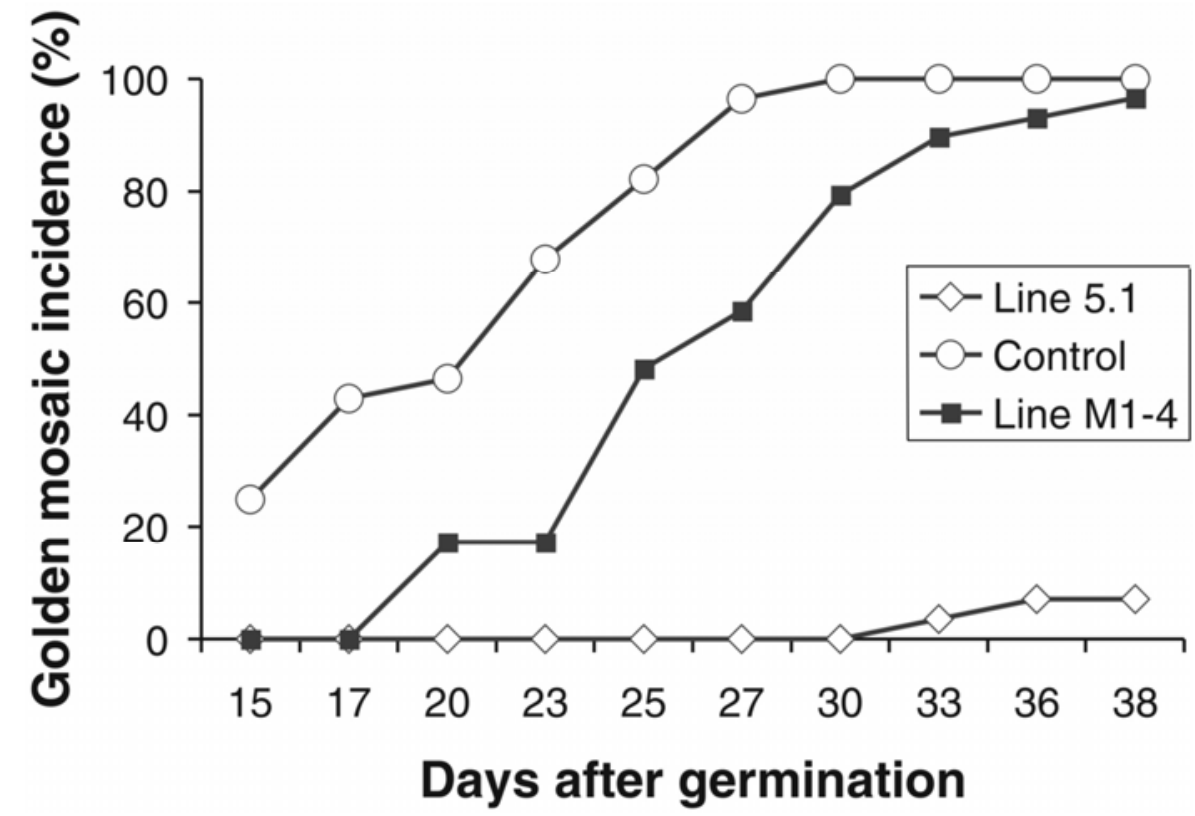

Fig. 7. Development of golden mosaic disease in transgenic bean lines challenged with Bean golden mosaic virus. Plants from the transgenic line 5.1 ( $\triangle A C 1$ intron-hairpin RNA line) $(n=28)$, transgenic line M1/4 (transdominant line) $(n=29)$, and control (nontransgenic) ( $n=28)$ were germinated in the presence of a population of viruliferous whiteflies. Disease evaluation was done visually by recording the first date of vein clearing. 
with a hairpin structure can induce PTGS with 90 to $100 \%$ efficiency when directed against RNA viruses or endogenous genes (Nunes et al. 2006; Smith et al. 2000; Wesley et al. 2001). The higher resistance frequency observed for RNA viruses could be due the fact that both RNA transcripts and genomic RNA can be targeted by the silencing machinery. In addition, geminiviruses accumulate within nuclei. Blevins and associates (2006) showed that two nuclear DNA viruses (a geminivirus and a pararetrovirus) and a cytoplasmic RNA tobamovirus are differentially targeted by subsets of Dicer-like proteins. This distinction probably reflects the fundamentally different lifecycle of DNA viruses, which includes a nuclear phase. Moreover, the expression of a transgene located in active chromatin or heterochromatin is highly variable, even among lines independently transformed with the same construct. Many factors may be responsible for variable transgene expression, including the tendency for exogenous DNA to undergo inverted repeat rearrangement prior to transformation by using direct methods, effects related to integration position and DNA hypermethylation (Meyer 1998).

The derived progeny revealed a non-Mendelian segregation pattern. However, the $\mathrm{R}_{2}$ generation presented a 3:1 Mendelian segregation. Moreover, Southern blot analysis carried out with plants from the $\mathrm{R}_{2}$ generation revealed that the transgenes were integrated in a single locus, corroborating the observed segregation fashion. This result suggests that the primary transformant was a chimeric plant. Indeed, chimerism commonly has been observed in leguminous plants transformed by particle bombardment of meristematic tissues (Aragão et al. 1996; Christou et al. 2006).

Advanced generations of transgenic line 5.1 were analyzed for their resistance to BGMV. Most plants (>92.9\%) remained without symptoms after exposure to a large number of viruliferous whiteflies for the period of the whole plant life cycle. In the field, a population of approximately 200 adult whiteflies per plant is considered an extremely severe infestation and 2 to 10 insects per plant generally leads to 90 to $100 \%$ disease incidence (F. Morales, personal communication). Approximately $7.1 \%$ of the transgenic plants presented mild symptoms in young leaves from the top 30 days after inoculation. Moreover, these plants presented similar growth when compared with uninfected plants and revealed no apparent reduction in the amount of seed produced. Further investigation is needed to determine the involvement of AC1siRNAs in regulating plant development.

RNA analysis of line 5.1 revealed the presence of siRNA only in transgenic plants, implying that resistance is due to an RNA-mediated mechanism. Gene silencing could be due to PTGS or dsRNA-triggering viral genome methylation and transcriptional inactivation in trans (Mette et al. 2000). In infected bean plants, virus-derived siRNA was not observed at 12 days after inoculation, even though symptoms were observed at day 14 after inoculation. This suggests that BGMV was unable to induce PTGS in the early stages of infection, despite the fact that transcript corresponding to the $A C 1$ gene probably is abundant early in the infection cycle. In contrast, it was observed that siRNA accumulation started 1 week after inoculation in plants of cassava and Nicotiana benthamiana infected with ACMV (Chellappan et al. 2004b). Because AC1, AC2, and $A C 3$ transcription may be expressed from a polycistronic mRNA (Hanley-Bowdoin et al. 1999), the transgene $\triangle A C$ 1 siRNA could serve as a primer for an RNA-dependent RNA polymerase, using the viral mRNA as a template (Brodersen and Voinnet 2006), to produce secondary siRNA molecules corresponding to other $A L 2$ and $A L 3$ genes. It would enlarge the probability of multiple virus species resistance. However, in bean transgenic plants infected with the
BGMV, siRNAs were not observed outside the region homologous to the triggering siRNA and representing parts of the $A C 2$ and $A C 3$ genes present in the target viral mRNA. Vanitharani and associates (2003) report the use of siRNAs to target green fluorescent protein $(g f p)$ gene expression and geminiviral DNA accumulation in cultured plant cells. siRNA representing parts outside the $g f p$ gene was detected in the region homologous to the triggering siRNA. Similarly, siRNA designed to target the mRNA encoding the AC1 protein of the ACMV was specific only against the parent sequence (Vanitharani et al. 2003).

Plant-virus interactions are affected by environmental factors, especially by temperature. The appearance of virus diseases commonly is associated with low temperature. At high temperature, viral symptoms frequently are attenuated and plants rapidly recover from virus diseases. Chellappan and associates (2005) showed that cassava geminivirus-derived siRNA increased by raising the temperature from 25 to $30^{\circ} \mathrm{C}$, with appearance of less symptomatic leaves. Szittya and associates (2003) demonstrated that RNA silencing-mediated plant defense is temperature dependent. At low temperature, both virus- and transgene-induced RNA silencing was inhibited, leading to enhanced virus susceptibility and loss of silencing-mediated transgenic phenotypes. Moreover, it was consistent with the reduction of transgene-derived siRNAs at low temperatures and increase with higher temperatures (Szittya et al. 2003). Our results demonstrated that the level of $A C 1$ siRNA was reduced when transgenic bean plants were cultivated at low temperature $\left(15^{\circ} \mathrm{C}\right)$, which could provoke a resistance decrease. However, it is important to note that common bean plants generally are cultivated in temperatures above $20^{\circ} \mathrm{C}$, because it is not unusual to have a decrease in temperature during commercial bean cultivation, especially in mid-altitude areas.

It has been suggested that a broad-spectrum geminivirus resistance could be achieved by using RNAi ACl-mediated resistance. The expression of the full-length $A C 1$ gene from ACMV in transgenic cassava conferred enhanced resistance to the homologous virus and cross-protection against the East African cassava mosaic Cameroon virus (EACMCV) and Sri Lanka cassava mosaic virus (SLCMV) (Chellappan et al. 2004b). siRNA designed to target the mRNA transcript encoding the glycoprotein $\mathrm{G}$, from a rhabdovirus in fish cell cultures, were effective against two other rhabdovirus species, even using siRNA molecules with four cases of mismatch compared with specific target sequence (Schyth et al. 2006). Besides BGMV, several other Phaseolus-infecting geminiviruses have been reported: Bean dwarf mosaic virus, Bean golden yellow mosaic virus, Euphorbia mosaic virus, and TYLCV (Jones 2003). Consequently, the development of broad resistance is desirable. In this work, we were able to test the transgenic bean lines only against BGMV because of biosafety and quarentenary restrictions. In silico analyses suggested that, theoretically, plants expressing the $\triangle A C l$ have a possibility to present some resistance to other geminiviruses. However, recent studies have suggested that, overall, Watson-Crick base pairing complementarity could not determine whether the expression of a particular gene will be affected by a given siRNA (Birmingham et al. 2006), and further experimental testing should be conducted to corroborate or refute in silico analysis.

Geminiviruses cause severe disease problems on several other crops throughout the world, such as cassava, cowpea, mungbean, pepper, melon, tomato, cotton blackgram, lima bean, soybean, potato, eggplant, pepper, chili pepper, watermelon, squash, and papaya (Morales 2006), and have been considered the "pest of the century" (Morales and Anderson 2001). The strategy presented here could be extended to achieve resistance against geminiviruses from other plant species. This work is an example of a public-sector effort to develop useful 
traits, such as resistance to a devastating disease, in an "orphan crop" cultivated by poor farmers throughout Latin America. It has the potential to become a milestone as one of the first "homemade" biotechnology crop improvement strategies performed in Brazil as a result of the interaction between bench and field scientists. Efforts are being made to test the BGMVresistant line in other countries, such as Argentina, Costa Rica, and the United States.

\section{MATERIALS AND METHODS}

\section{RNAi construct.}

Two fragments containing a partial sequence from $A C 1$ gene, both from position 1,836 to 2,247 (GenBank accession number M88686) were amplified by PCR. Primer pair HPXBA (5'-GTCTAGATAGTGGGGTGCGAT-3') and HPCLA (5'-GAT CGATGCGGCATCCGAAGC-3') ([including the sites for $\mathrm{XbaI}$ and $C l a$ I [underlined], respectively) was used to amplify a 421bp fragment from the BGMV genome. Primer pair HPXHO (5'CCTCGAGATAGTGCGGTGCGA-3') and HPKPN (5'-AGGT ACCATGCGGCATCCGAAGC-3') (including the sites for XhoI and $K p n I$ [underlined], respectively) was used to amplify a 424-bp fragment from the BGMV genome. The size and sequence within the $A C l$ viral gene were chosen on the basis of in silico analysis carried out using Mfold (Zucker 2003) and ILM (Ruan et al. 2004) algorithms, using the negative viral strand. PCR reactions were carried out in a thermocycler (PTC-100; MJ Research, Watertown, MA, U.S.A.) in a 50- $\mu 1$ solution containing $40 \mathrm{ng}$ of DNA, $60 \mathrm{mM}$ Tris-SO $\mathrm{SO}_{4}(\mathrm{pH} \mathrm{8.9)}$ ), $18 \mathrm{mM}\left(\mathrm{NH}_{4}\right)_{2} \mathrm{SO}_{4}, 2 \mathrm{mM} \mathrm{MgSO}$, $250 \mathrm{nM}$ each dNTP, 200 $\mathrm{nM}$ each primer, and $5 \mathrm{U}$ of platinum Taq DNA polymerase high fidelity (Invitrogen, Carlsbad, CA, U.S.A.). The mixture was treated at $95^{\circ} \mathrm{C}(5 \mathrm{~min})$ and subjected to 35 cycles of amplification $\left(95^{\circ} \mathrm{C}\right.$ for $1 \mathrm{~min}, 55^{\circ} \mathrm{C}$ for $1 \mathrm{~min}$, and $72^{\circ} \mathrm{C}$ for $\left.1 \mathrm{~min}\right)$, with a final elongation cycle of $5 \mathrm{~min}$ at $72^{\circ} \mathrm{C}$. The $411-\mathrm{bp}$ fragments were cloned into the pGEMT-Easy vector for PCR products (Promega Corp., Madison, WI, U.S.A.) and sequenced by using universal M13 and T7 primers on automatic sequencer (ABI Prism1 3700). The BGMV fragments were excised from pGEMT-Easy with $\mathrm{XbaI} / \mathrm{ClaI}$ and $\mathrm{XhoI} / \mathrm{KpnI}$, respectively, and inserted into the vector pKannibal (Wesley et al. 2001) to generate the plasmid $\mathrm{pKBGMVXCXK}$. The interfering cassette was removed with NotI from the vector pKBGMVXCXK and cloned into the site for NotI in the vector pAC321, which contains the gene ahas (that confers tolerance for the herbicide imazapyr) from Arabidopsis thaliana (Aragão et al. 2000), generating the vector pBGMVRNAiAHAS. The cassette containing the BGMV sequence hairpin will be mentioned hereafter as $\triangle A C l$ (Fig. 1).

\section{Common bean transformation.}

The plasmid vector pBGMVRNAiAHAS was used to transform common bean (cv. Olathe Pinto) according to Aragão and associates (1996), except that the herbicide imazapyr was used as a selective agent. Briefly, mature seed were surface sterilized and soaked in distilled water for 16 to $18 \mathrm{~h}$. Then, the embryonic axes were excised from the seed and the apical meristems were exposed by removing the primary leaves. The embryonic axes were placed with the apical region directed upward in petri dishes containing basal Murashige-Skoog (MS) medium immediately before bombardment. For transformation, the vector pBGMVRNAiAHAS was digested with FspI to disrupt the ampicillin resistance gene (bla) present in the vector backbone. Bombardment was conducted using a high-pressure, helium-driven particle acceleration device built in our laboratory. Immediately after bombardment, embryonic axes were transferred to MS medium containing $44.3 \mu \mathrm{M}$ ben- zylaminopurine and $80 \mathrm{nM}$ imazapyr. The concentration of the herbicide imazapyr previously was optimized to adequately select transgenic cells. After 3 weeks in culture, the bombarded apical meristems produced elongated shoots, which were allowed to reach 2 to $4 \mathrm{~cm}$ in length. The shoots $\left(\mathrm{T}_{0}\right.$ generation) were rooted and transferred to a plastic pot containing autoclaved soil:vermiculite (1:1) and covered with a plastic bag for a week to acclimatize. To detect the presence of foreign genes, plants were screened by PCR.

\section{Screening of transgenic plants by PCR analysis.}

DNA was isolated from seed or leaf disks according to Edwards and associates (1991). PCR reactions were carried out as described above, except that $\mathrm{MgSO}_{4}$ was replaced by $\mathrm{MgCl}_{2}$, and the platinum Taq DNA polymerase high fidelity was replaced by Taq polymerase (Invitrogen). The primers HPBGMVXHO and HPBGMVKPN were used to amplify a 421-bp fragment from the $\triangle A C 1$ sequence. Primers $5^{\prime}$-ACTAG AGATTCCAGCGTCAC-3' (AHAS124P) and 5'-GTGGCTAT ACAGATACCTGG-3' (AHAS500C) were used to amplify a 685-bp sequence from the ahas gene. Reaction mixtures then were loaded directly onto a $1 \%$ agarose gel stained with ethidium bromide and visualized with UV light.

\section{RNAi analysis.}

Eight-day-old seedlings were inoculated with the virus using 200 to 300 whiteflies/plant for a period of 6 days. After this period, whiteflies were removed. Total RNA was isolated from leaves, 6 and 12 days after initiation of virus inoculation, by extraction with Trizol (Invitrogen) as recommended by the manufacturer. Total RNA $(50 \mu \mathrm{g})$ was separated by $20 \%$ PAGE with $7 \mathrm{M}$ urea and $1 \times$ Tris-borate-EDTA (TBE). The gel was stained with a $1 \times$ TBE containing ethidium bromide $(0.5$ $\mu \mathrm{g} / \mathrm{ml}$ ), and photographed to verify normalization by visualization of tRNAs and 5S rRNA. RNAs were electroblotted to a Hybond-N+ membrane (Amersham Pharmacia Biotech, Buckinghamshire, U.K.), UV fixed, and hybridized with a DNA probe corresponding to the PCR fragment amplified using the primer pair HPXHO/HPKPN (within the ACl gene, from 1,838 to 2,232 in the BGMV DNA-A genome), primer pair AC2F (5'TGTACGTAAATTGTGCAGCCGC-3')/AC2R (5'-AGGTGGA ATCCCATCAATCGTG-3') (within the AC2 gene, position 1,526 to 1,751 in the BGMV DNA-A genome), and primer pair AC3F (5'-TGTTGCGAAACGTACAGCTCTG-3')/AC3R (5'CACAACGACCAGAGTATACCAC- $3^{\prime}$ ) (within the $A C 3$ gene, from 1,170 to 1,392 in the BGMV DNA-A genome). Probes were labeled with $\alpha^{32} \mathrm{P}$ dCTP using a random primer DNA labeling kit (Amersham Pharmacia Biotech) according to the manufacturer's instructions. Hybridization and posthybridization washes were conducted as described (Yoo et al. 2004). Three oligomers $(18,24$, and 44 nucleotides) were used as molecular size markers. $A C 1$-, $A C 2$-, and $A C 3$-sequence-related 21-nucleotide oligomers were used as positive controls.

For temperature treatment, plants at 1 week after germination were maintained in a growth chamber (Conviron, Winnipeg, Canada) at 15,25 , and $35^{\circ} \mathrm{C}, 85 \%$ relative humidity, under light intensity of $200 \mu \mathrm{mol} \mathrm{m} \mathrm{s}^{-1}$ (16 h of light and $8 \mathrm{~h}$ of dark) for a period of 1 week. Leaves were collected for total RNA extraction as described.

\section{Southern blot analysis.}

Genomic DNA was isolated using the DNeasy Plant Mini Kit (Qiagen, Valencia, CA, U.S.A.). Southern blotting was carried out as described (Sambrook and Russell 2001). Genomic DNA $(15 \mu \mathrm{g})$ was digested with XhoI, separated on a $1 \%$ agarose gel, and transferred to a nylon membrane (Hybond-N+; Amersham Pharmacia Biotech). Hybridizations were carried 
out using the intron from $p d k$ gene (Wesley et al. 2001) present in the vector pBGMVRNAiAHAS, labeled with $\alpha^{32} \mathrm{P}$ dCTP (3000 $\mathrm{Ci} \mathrm{mol}^{-1}$ ) using a random primer DNA-labeling kit (Amersham Pharmacia Biotech) according to the manufacturer's instructions.

\section{Plant inoculation with BGMV and symptom evaluation.}

Transgenic plants $\left(\mathrm{T}_{0}\right.$ generation) were inoculated with BGMV by exposure for 2 to 3 days to 70 viruliferous whiteflies. Transgenic advanced generations were analyzed for their resistance to BGMV by a very high inoculation pressure, using 110 to 357 viruliferous whiteflies per plant for a period of up to 13 days, using 8-day-old seedlings. A viruliferous whitefly colony was maintained on P. lunatus L. and Glycine max Merrill, with the periodic replacement of older plants by young ones. After the inoculation period, the insects were removed and the plants transferred to an insect-free greenhouse for symptom development and evaluation. Evaluations were carried out by recording the first date of vein clearing, and then daily until full disease symptoms had developed. In all, 20 to 25 plants of each transgenic or nontransgenic bean cultivar were used for each experiment.

To compare the resistance observed in line 5.1 with a tolerant transgenic transdominant line (Faria et al. 2006), homozygous plants $\left(\mathrm{R}_{3}\right.$ generation) were germinated in the presence of the viruliferous whitefly colony. Plants were maintained in contact with viruliferous whiteflies during a period of 38 days. Whiteflies were not eliminated during the evaluation period. Evaluations were done by recording the first date of vein clearing and then daily until full disease symptoms had developed on control plants.

\section{PCR analysis for virus detection.}

PCR analyses were carried out to detect BGMV in bean leaves using the protocol described above. Primers 5'TGTTGCGAAACGTACAGCTCTG-3' (AC3F) and 5'-CACA ACGACCAGAGTATACCAC-3' (AC3R) were used to amplify a 223-bp sequence from the BGMV genome (DNA-A).

For semiquantitative analyses, PCR reactions were carried out as described above, except that 30 cycles of amplification were used. The number of amplification cycles previously was optimized to stop the reaction at the exponential stage, ensuring that amplification was semiquantitative. As an internal control, primers rRNA1 (5'-AACGGCTACCACATCCAAGG$\left.3^{\prime}\right)$ and rRNA2C (5'-TCATTACTCCGATCCCGAAG-3') were used to amplify a sequence of 458 bp within the $P$. vulgaris $18 \mathrm{~S}$ rRNA gene (TIGR $P$. vulgaris Gene Index, TC238). Experiments were repeated twice.

\section{ACKNOWLEDGMENTS}

We gratefully acknowledge the financial support of FINEP (Financiadora de Estudos e Projetos). K. Bonfim was supported by a fellowship from CAPES (Coordenação de Aperfeiçoamento de Pessoal de Nível Superior).

\section{LITERATURE CITED}

Antignus, Y., Vunsh, R., Lachman, O., Pearlsman, M., Maslenin, L., Hananya, U., and Rosner, A. 2004. Truncated Rep gene originated from Tomato yellow leaf curl virus-Israel (Mild) confers strain-specific resistance in transgenic tomato. Ann. Appl. Biol. 144:39-44.

Aragão, F. J. L., Barros, L. M. G., Brasileiro, A. C. M., Ribeiro, S. G., Smith, F. D., Sanford, J. C., Faria, J. C., and Rech, E. L. 1996. Inheritance of foreign genes in transgenic bean (Phaseolus vulgaris L.) cotransformed via particle bombardment. Theor. Appl. Genet. 93:142150 .

Aragão, F. J. L., Ribeiro, S. G., Barros, L. M. G., Brasileiro, A. C. M., Maxwell, D. P., Rech, E. L., and Faria, J. C. 1998. Transgenic beans
(Phaseolus vulgaris L.) engineered to express viral antisense RNAs show delayed and attenuated symptoms to bean golden mosaic geminivirus. Mol. Breed. 4:491-499.

Aragão, F. J. L., Sarokin, L., Vianna, G. R., and Rech, E. L. 2000. Selection of transgenic meristematic cells utilizing a herbicidal molecule results in the recovery of fertile transgenic soybean (Glycine max (L.) Merrill) plants at high frequency. Theor. Appl. Genet. 101:1-6.

Asad, S., Haris, W. A., Bashir, A., Zafar, Y., Malik, K. A., Malik, N. N., and Lichtenstein, C. P. 2003. Transgenic tobacco expressing geminiviral RNAs are resistant to the serious viral pathogen causing cotton leaf curl disease. Arch. Virol. 148:2341-2352.

Bejarano, E. R., and Lichtenstein, C. P. 1994. Expression of TGMV antisense RNA in transgenic tobacco inhibits replication of BCTV but not ACMV geminiviruses. Plant Mol. Biol. 24:241-248.

Bendahmane, M., and Gronenborn, B. 1997. Engineering resistance against Tomato yellow leaf curl virus (TYLCV) using antisense RNA. Plant Mol. Biol. 33:351-357.

Bian, X.-Y., Rasheed, M. S., Seemanpillai, M. J., and Rezaian1, M. A. 2006. Analysis of silencing escape of Tomato leaf curl virus: an evaluation of the role of DNA methylation. Mol. Plant-Microbe Interact. 19:614-624.

Birmingham, A., Anderson, E. M., Reynolds, A., Ilsley-Tyree, D., Leake, D., Federov, Y., Baskerville, S., Maksimova, E., Robinson, K., Karpilow, J., Marshall, W. S., and Khvorova, A. 2006. 3' UTR seed matches, but not overall identity, are associated with RANi off-targets. Nat. Methods 3:199-204.

Blevins, T., Rajeswaran, R., Shivaprasad, P. V., Beknazariants, D., SiAmmour, A., Park, H., Vazquez, F., Robertson, D., Meins, F., Hohn, T., and Pooggin, M. M. 2006. Four plant Dicers mediate viral small RNA biogenesis and DNA virus induced silencing. Nucleic Acids Res. 34:6233-6246

Brodersen, P., and Voinnet, O. 2006. The diversity of RNA silencing pathways in plants. Trends Genet. 22:268-280.

Brunetti, A., Tavazza, M., Noris, E., Tavazza, R., Caciagli, P., Ancora, G., Crespi, S., and Accotto, G. P. 1997. High expression of truncated viral Rep protein confers resistance to Tomato yellow leaf curl virus in transgenic tomato plants. Mol. Plant-Microbe Interact. 10:571-579.

Brunetti, A., Tavazza, R., Noris, E., Lucioli, A., Accotto, G. P., and Tavazza, M. 2001. Transgenically expressed T-Rep of Tomato yellow leaf curl Sardinia virus acts as a trans-dominant-negative mutant, inhibiting viral transcription and replication. J. Virol. 75:10573-10581.

Chellappan, P., Masona, M. V., Vanitharani, R., Taylor, N. J., and Fauquet, C. M. 2004a. Broad spectrum resistance to ssDNA viruses associated with transgene-induced gene silencing in cassava. Plant Mol. Biol. 56:601-611.

Chellappan, P., Vanitharani, R., and Fauquet, C. M. 2004b. Short interfering RNA accumulation correlates with host recovery in DNA virusinfected hosts, and gene silencing targets specific viral sequences. J. Virol. 78:7465-7477.

Chellappan, P., Vanitharani, R., Ogbe, F., and Fauquet, C. M. 2005. Effect of temperature on geminivirus-induced RNA silencing in plants. Plant Physiol. 138:1828-1841.

Christou, P., Capell, T., Kohli, A., Gatehouse, J. A., and Gatehouse, A. M R. 2006. Recent developments and future prospects in insect pest control in transgenic crops. Trends Plant Sci. 11:302-308.

Day, A. G., Bejarano, E. R., Buck, K. W., Burrell, M., and Lichtenstein, C. P. 1991. Expression of an antisense viral gene in transgenic tobacco confers resistance to the DNA virus Tomato golden mosaic virus. Proc. Natl. Acad. Sci. U.S.A. 88:6721-6725.

Duan, Y. P., Powell, C. A., Purcifull, D. E., Broglio, P., and Hiebert, E. 1997. Phenotypic variation in transgenic tobacco expressing mutated geminivirus movement/pathogenicity (BC1) proteins. Mol. PlantMicrobe Interact. 10:1065-1074.

Eagle, P. A., Orozco, B. M., and Hanley-Bowdoin, L. 1994. A DNA sequence required for geminivirus replication also mediates transcriptional regulation. Plant Cell 6:1157-1170.

Edwards, K., Johnstone, C., and Thompson, C. 1991. A simple and rapid method for the preparation of plant genomic DNA for PCR analysis. Nucleic Acids Res. 19:1349.

Elmer, J. S., Brand, L., Sunter, G., Gardiner, W. E., Bisaro, D. M., and Rogers, S. G. 1988. Genetic analysis of the Tomato golden mosaic virus ii. the product of the AL1 coding sequence is required for replication. Nucleic Acids Res. 16:7043-7060.

Faria, J. C., Albino, M. M. C., Dias, B. B. A., Cançado, L. J., Cunha, N. B., Silva, L. M., Vianna, G. R., and Aragão, F. J. L. 2006. Partial resistance to Bean golden mosaic virus in a transgenic common bean (Phaseolus vulgaris) line expressing a mutant rep gene. Plant Sci. 171:565-571.

Fuentes, A., Ramos, P., Fiallo, E., Callard, D., Sánchez, Y., Peral, R., Rodrýguez, R., and Pujol, M. 2006. Intron-hairpin RNA derived from replication associated protein $\mathrm{C} 1$ gene confers immunity to Tomato yel- 
low leaf curl virus infection in transgenic tomato plants. Transgenic Res. 15:291-304

Garrido-Ramirez, E. R., Sudarshana, M. R., Lucas, W. J., and Gilbertson, R. L. 2000. Bean dwarf mosaic virus BV1 protein is a determinant of the hypersensitive response and avirulence in Phaseolus vulgaris. Mol. Plant-Microbe Interact. 13:1184-1194.

Hanley-Bowdoin, L., Settlage, S. B., Orozco, B. M., Nagar, S., and Robertson, D. 1999. Geminiviruses: models for plant DNA replication, transcription, and cell cycle regulation. Crit. Rev. Plant. Sci. 18:71-106.

Hao, L., Wang, H., Sunter, G., and Bisaro, D. M. 2003. Geminivirus AL2 and L2 proteins interact with and inactivate SNF1 kinase. Plant Cell 15:1034-1048.

Herr, A. J. 2005. Pathways through the small RNA world of plants. FEBS (Fed. Eur. Biol. Soc.) Lett. 579:5879-5888.

Hong, Y., and Stanley, J. 1996. Virus resistance in Nicotiana benthamiana conferred by African cassava mosaic virus replication-associated protein (AC1) transgene. Mol. Plant-Microbe Interact. 9:219-225.

Jones, D. R. 2003. Plant viruses transmitted by whiteflies. Eur. J. Plant Pathol. 109:195-219.

Kjemtrup, S., Sampson, K. S., Peele, C. G., Nguyen, L. V., Conkling, M A., Thompson, W. F., and Robertson, D. 1998. Gene silencing from plant DNA carried by a genimivirus. Plant J. 14:91-100.

Kunik, T., Salomon, R., Zamir, D., Navot, N., Zeidan, M., Michelson, I., Gafni, Y., and Czosnek, H. 1994. Transgenic tomato plants expressing the Tomato yellow leaf curl virus capsid protein are resistant to the virus. Bio/Technology 12:500-504.

Lucioli, A., Noris, E., Brunetti, A., Tavazza, R., Ruzza, V., Castillo, A. G., Bejarano, E. R., Accotto, G. P., and Tavazza, M. 2003. Tomato yellow leaf curl Sardinia virus Rep-derived resistance to homologous and heterologous geminiviruses occurs by different mechanisms and is overcome if virus-mediated transgene silencing is activated. J. Virol. 77:6785-6798.

Mette, M. F., Aufsatz, W., van der Winden, J., Matzke, M. A., and Matzke, A. J. 2000. Transcriptional silencing and promoter methylation triggered by double-stranded RNA. EMBO (Eur. Mol. Biol. Organ.) J. 19:5194-5201.

Meyer, P. 1998. Stabilities and instabilities in transgene expression. Pages 263-275 in: Transgenic Plant Research. K. Lindsey, ed. Harwood Academic Publishers, Amsterdam, The Netherlands.

Morales, F. J. 2006. History and current distribution of begomoviruses in Latin America. Adv. Virus Res. 67:127-162.

Morales, F. J., and Anderson, P. K. 2001. The emergence and dissemination of whitefly-transmitted geminiviruses in Latin America. Arch. Virol. 146:415-441.

Noris, E., Aecoto, P., Tavazza, R; Brunetti, A., Crespi, S., and Tavazza, M. 1996. Resistance to tomato yellow leaf curi geminivirus in Nícotiana benthamiana plants transformed with a truncated viral $\mathrm{Cl}$ gene. Virology 224:130-138

Noris, E., Lucioli, A., Tavazza, R., Caciagli, P., Accotto, G. P., and Tavazza, M. 2004. Tomato yellow leaf curl Sardinia virus can overcome transgene-mediated RNA silencing of two essential viral genes. J. Gen. Virol. 85:1745-1749.

Nunes, A. C. S., Vianna, G. R, Cuneo, F., Amaya-Farfán, J., Capdeville, G., Rech, E. L., and Aragão, F. J. L. 2006. RNAi-mediated silencing of the myo-inositol-i-phosphate syntase gene (GmMIPS1) in transgenic soybean inhibited seed development and reduced phytate content. Planta 224:125-132.

Pooggin, M. M., Shivaprasad, P. V., Veluthambi, K., and Hohn, T. 2003. RNAi targeting of DNA virus in plants. Nat. Biotechnol. 21:131-132.

Prins, M. 2003. Broad virus resistance in transgenic plants. Trends Biotechnol. 21:373-375.

Ruan, J., Stormo, G. D., and Zhang, W. 2004. ILM: a web server for predicting RNA secondary structures with pseudoknots. Nucleic Acids Res. 32:147-149.

Sambrook J., and Russell, D. W. 2001. Molecular Cloning: A Laboratory Manual, 3rd ed. Cold Spring Harbor Laboratory Press, Cold Spring Harbor, NY, U.S.A.

Seo, Y. S., Gepts, P., and Gilbertson, R. L. 2004. Genetics of resistance to the geminivirus, Bean dwarf mosaic virus, and the role of the hypersensitive response in common bean. Theor. Appl. Genet. 108:786-793.
Schyth, B. D., Lorenzen, N., and Pedersen, F. S. 2006. Antiviral activity of small interfering RNAs: Specificity testing using heterologous virus reveals interferon-related effects overlooked by conventional mismatch controls. Virology 349:134-141.

Smith, N. A., Singh, S. P., Wang, M. B., Stoutjesdijk, P. A., Green, A. G., and Waterhouse, P. M. 2000. Total silencing by intorn-spliced hairpin RNAs. Nature 407:319-320.

Stanley, J., Frischmuth, T., and Ellwood, S. 1990. Defective viral DNA ameliorates symptoms of geminivirus infection in transgenic plants. Proc. Natl. Acad. Sci. U.S.A. 87:6291-6295.

Sunter, G., and Bisaro, D. M. 1992. Transactivation of geminivirus AR1 and BR1 gene expression by the viral AL2 gene product occurs at the level of transcription. Plant Cell 4:1321-1331.

Sunter, G., and Bisaro, D. M. 1997. Regulation of a geminivirus coat protein promoter by AL2 protein (TrAP): evidence for activation and derepression mechanisms. Virology 232:269-280.

Sunter, G., Hartitz, M. D., Hormuzdi, S. G., Brough, C. L., and Bisaro, D. M. 1990. Genetic analysis of tomato golden mosaic virus ORF AL2 is required for coat protein accumulation while ORFAL3 is necessary for efficient DNA replication. Virology 179:69-77.

Szittya, G., Silhavy, D., Molnar, A., Havelda, Z., Lovas, A., Lakatos, L. Banfalvi, Z., and Burgyan, J. 2003. Low temperature inhibits RNA silencing-mediated defense by the control of siRNA generation. EMBO (Eur. Mol. Biol. Organ.) J. 22:633-640.

Trinks, D., Rajeswaran, R., Shivaprasad, P. V., Akbergenov, R., Oakeley, E. J., Veluthambi, K., Hohn, T., and Pooggin, M. M. 2005. Suppression of RNA silencing by a geminivirus nuclear protein, AC2, correlates with transactivation of host genes. J. Virol. 79:2517-2527.

Vanderschuren, H., Stupak, E., Fütterer, M., Gruissem, J., and Zhang, W. 2006. Engineering resistance to geminiviruses-review and perspectives. Plant Biotechnol. J. 4:1-14.

Vanitharani, R., Chellappan, P., and Fauquet C. M. 2003. Short interfering RNA-mediated interference of gene expression and viral DNA accumulation in cultured plant cells. Proc. Natl. Acad. Sci. U.S.A. 100:96329636.

Vanitharani, R., Chellappan, P., and Fauquet, C. M. 2005. Geminiviruses and RNA silencing. Trends Plant Sci. 10:144-151.

Veltcheva, M., Svetleva, D., Petkova, S., and Perl, A. 2005. In vitro regeneration and genetic transformation of common bean (Phaseolus vulgaris L.)—Problems and progress. Sci. Hortic. 107:2-10.

Vianna, G. R., Albino, M. M. C., Dias, B. B. A., Silva, L. M., Rech, E. L., and Aragão, F. J. L. 2004. Fragment DNA as vector for genetic transformation of bean (Phaseolus vulgaris L.). Sci. Hortic. 99:371-378.

von Arnim, A., and Stanley, J. 1992. Determinants of Tomato golden mosaic virus symptom development located on DNA B. Virology 186:286293.

Wang, H., Hao, L. H., Shung, C. Y., Sunter, G., and Bisaro, D. M. 2003. Adenosine kinase is inactivated by geminivirus AL2 and L2 proteins. Plant Cell 15:3020-3032.

Wang, H., Buckley, K. J., Yang, X., Buchmann, R. C., and Bisaro, D. M. 2005. Adenosine kinase inhibition and suppression of RNA silencing by geminivirus AL2 and L2 proteins. J. Virol. 79:7410-7418.

Waterhouse, P. M., Wang, M. B., and Lough, T. 2001. Gene silencing as an adaptive defence against viruses. Nature 411:834-842.

Wesley, S., Helliwell, C., Smith, N., Wang, M., Rouse, D., Liu, Q., Gooding, P., Singh, S., Abbott, D., Stoutjesdijk, P., Robinson, S., Gleave, A., Green, A., and Waterhouse, P. 2001. Construct design for efficient, effective and high-throughput gene silencing in plants. Plant J. 27:581-590.

Yang, Y., Sherwood, T. A., Hiebert, C. P., and Polston, J. E. 2004. Use of Tomato yellow leaf curl virus (TYLCV) Rep gene sequences to engineer TYLCV resistance in tomato. Phytopathology 94:490-496.

Yoo, B. C., Kragler, F., Varkonyi Gasic, E., Haywood, V., Archer Evans, S., Lee, Y. M., Lough, T. J., and Lucas, W. J. 2004. A systemic small RNA signaling system in plants. Plant Cell 16:1979-2000.

Zhang, P., Vanderschuren, H., Futterer, J., and Gruissem, W. 2005. Resistance to cassava mosaic disease in transgenic cassava expressing antisense RNAs targeting virus replication genes. Plant Biotechnol. J. 3:385-397.

Zucker, M. 2003. Mfold web server for nucleic acid folding and hybridization prediction. Nucleic Acids Res. 31:3406-3415. 